\title{
EVALUATION OF WOOD SURFACE ROUGHNESS DEPENDING ON SPECIES CHARACTERISTICS
}

\author{
Hektor Thoma ${ }^{1, \wedge}$, Leonidha Peri ${ }^{2}$, Entela Lato ${ }^{3}$
}

\begin{abstract}
This study is focused on the impacts of species characteristics on the surface roughness of five species with different wood density namely white fir, Aleppo pine, European beech, walnut and white oak.

The sample specimens tested were $300 \times 300 \times 30 \mathrm{~mm}$ in size and their surface quality was evaluated by the "the direct contact method" based on a mechanical system of measurement, giving the possibility of reproducing the surface measured and analyzing its profile.

The surface roughness measurements were performed with a contact stylus profilometer, holding the moisture content of the specimens constant at $10 \%$. The evaluation of the surface characteristics of the wood samples considered the roughness parameters: arithmetic mean deviation of the profile, maximum two point height of the profile, mean roughness depth and root-mean-square deviation of the profile.

From the study result showed different average values of surface roughness parameters for broadleaved and conifers species. The differences can be explain by the influence on the roughness of the wood surface of the wood texture and the texture uniformity.
\end{abstract}

Keywords: Cutting regime, roughness parameter, roughness profile, surface roughness, wood density.

\section{INTRODUCTION}

The surface of wood is the result of complex factors including the interaction of raw material used, types of processes and time. Usually the surface of manufactured wood elements results from a partitioning process achieved through one or more consecutive cutting and smoothing steps, which might include traditional sawing, planning, milling or sanding process, or modern laser- or water-jet cutting. Each of these processes normally has their individual characteristics, which will result in wood surfaces with different properties (Sinn et al. 2009). Mitchell and Lemaster (2002) studied the effect of machine parameters on the surface quality as a function of feed speed, spindle speed, tool direction and tool wear.

During cutting processes, various anatomical parts of wood are separated and the properties of the separated pieces are influenced by the grain pattern and, physical and mechanical properties of wood. Grain structure make the micro-geometry of the created wood surfaces heterogeneous. Goli (2003), Goli et al. $(2004,2005)$ have systematically studied the effects of grain direction on the machined surface geometry, and especially the occurrence of certain surface defects, e.g., fuzzy grain. These authors have also discussed the mechanisms of defect formation, such as kinematics, cutting forces, shear induced splitting, transverse compression and tension, and presented experimental observations, which give directives for optimized cutting procedures in relations to surface roughness.

\footnotetext{
Faculty of Forestry Sciences, Department of Wood Industry, 1029 Koder-Kamez, E-mail: hektor_thoma@hotmail.com, Tirana, Albania.

${ }^{2}$ Faculty of Forestry Sciences, Department of Forestry, 1029 Koder-Kamez, Tirana, Albania.

${ }^{3}$ Faculty of Forestry Sciences, Department of Wood Industry, 1029 Koder-Kamez, Tirana, Albania.

•Corresponding author: hektor_thoma@hotmail.com

Received: 12.07.2013 Accepted: 05.07.2014
} 
Cutting conditions clearly affect the cutting energy, cutting forces and consequently the quality of wood surface (Aguilera and Muñoz 2011, Aguilera and Zamora 2009). Surface roughness is strongly and directly linked or influenced by the future use of the wood material/element. An effective control of the surface roughness is important in production processes related to adhesive bonding of wood elements and final processing of finished products (Lemaster et al. 1982). Many studies (Tanaka 1991, Lavery et al. 1995, Hecker and Becker 1995) indicate that the surface roughness is strongly influenced by wood density.

In order to determine the surface roughness of wood, several methods are used in the wood processing industry starting with methods based on the visual and tactile senses and methods using surface-measuring equipment. The first group of methods interpret the surface roughness based on physical characteristics linked between them (pressure, touch, rubbing) and normally provide a faster and more economical measurement than methods using surface-measuring equipment (Fujiwara et al. 2005).

There are no standards for the measurements of wood surfaces, because of the irregularity of the processed wood surfaces due to cellular structure of wood and machining processes, which make the application of standards unreliable (Funck et al. 1992, Krisch and Csiha 1999).

This study was undertaken to fill an existing gap in the field of wood surface properties research. There have been until now no such studies in the country and it had to be seen as the first attempt to research the surface roughness parameters of the most used timber species in Albania.

\section{MATERIALS AND METHODS}

This study was focused on the evaluation of the quality of wood surface and involved samples from five forest species with different wood density namely white fir (Abies alba Mill), Aleppo pine (Pinus halepensis Mill), European beech (Fagus sylvatica L.), walnut (Juglans regia L.) and white oak (Quercus petraea Liebl), which grow in Albania and with the exception of Aleppo Pine are used in the wood processing industry as raw materials.

The sample specimens tested were sized at 300x300x30 mm. To evaluate their surface quality "the direct contact method" based on a mechanical system of measurement, was used giving the possibility of reproducing the surface measured and analyzing its profile.

According to Goli (2003) in order to better evaluate the surface quality of the primary profile should be analyzed. The primary profile is thus the sum of all the deviations of the measured profile from the nominal profile. The primary profile is the sum of the form error profile, the waviness profile, and the roughness profile and is normally computed from the traced profile by excluding the nominal form by using the method of best fit least squares of the type and by excluding ultra-short wavelengths from the evaluation by using the "ls" profile filter, which considerably increases comparability.

The distinction between the primary profile, roughness profile and waviness profile is shown in figure 1 . All the definitions used and parameters measured or calculated in this study are given in ISO 3274 (1996), ISO 4287 (1998) and DIN 4768 (1990) standards. According to ASME B46.1 (2009), any measured surface represents a superposition of form errors, waviness and roughness. Measured data should be filtered so as to retain from a surface profile only the data that is relevant for characterizing the quality of the manufacturing process. 


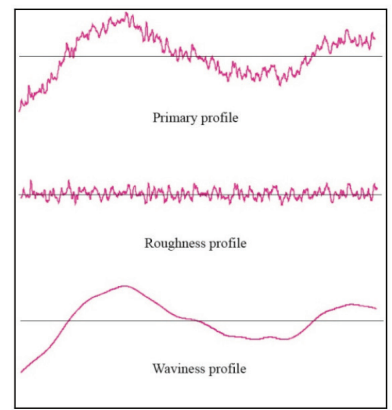

Figure 1. Distinctions between Primary Profile, Roughness Profile and Waviness Profile.

Measurements were done with a Contact Stylus Profilometer type Mitutoyo SJ-201. With the equipment a direct measure of the necessary parameters needed to build a two-dimensional surface profile is possible. The measured parameters were:

1. Arithmetic mean deviation of the profile, $\mathrm{Pa}$

2. Maximum two point height of the profile, Py

3. Mean roughness depth, $\mathrm{Pz}$

4. Root-mean-square deviation of the profile, $\mathrm{Pq}$

$\mathrm{Pa}$ is the average distance from the profile to the mean line over the length of assessment, $\mathrm{Pq}$ is the square root of the arithmetic mean of the squares of profile deviations from the mean line, $\mathrm{Pz}$ can be calculated from the peak-to-valley values of five equal lengths within the profile, while maximum roughness (Py) is the distance between peak and valley points of the profile which can be used as an indicator of the maximum defect height within the assessed profile.

The sampling length was $2,5 \mathrm{~mm}$ and the evaluation length $12,5 \mathrm{~mm}$. The measuring force of the scanning arm of the equipment on the specimens surfaces was $4 \mathrm{mN}(0,4 \mathrm{gf})$, which did not put any significant damage on the surface. The measurements were made in the direction perpendicular to the fiber of the sample specimens and the traversing speed was approx. $0,5 \mathrm{~mm} / \mathrm{s}$.

The evaluated sample specimens were first processed in a planing machine with the parameters shown in the table 1 and then finished in the sanding machine with a feed of $10 \mathrm{~m} / \mathrm{min}$ and using a sandpaper with 120 grit size. The specimens evaluated were all defect free.

Table 1. Planning machine parameters.

\begin{tabular}{|l|r|}
\hline Cutting width & $30 \mathrm{~mm}$ \\
\hline Rotation speed & $4500-6000 \mathrm{rpm}$ \\
\hline Depth of cut & $2 \mathrm{~mm}$ \\
\hline Feed speed & $5-7-10 \mathrm{~m} / \mathrm{min}$ \\
\hline No. of knives & 4 \\
\hline
\end{tabular}




\section{RESULTS AND DISCUSSION}

The results of the measurements of the above mentioned parameters are shown in table 2 . The values in the table 2 are average values of the surface roughness parameters and their standard deviations measured for different wood species specimens processed only in the planing machine. Several measurements were done at different points of the wood surface and then the average value was calculated.

Table 2. Average values of the surface roughness parameters after processing in the planning machine.

\begin{tabular}{|c|c|c|c|c|c|c|c|}
\hline Species & $\begin{array}{l}\text { Density } \\
\left(\mathrm{kg} / \mathrm{m}^{3}\right)\end{array}$ & \begin{tabular}{|c|}
$\mathbf{E W} / \mathbf{L W}$ \\
transition $^{\mathrm{a}}$
\end{tabular} & & $\begin{array}{c}\mathbf{P a} \\
(\mu \mathrm{m})\end{array}$ & $\begin{array}{c}\text { Py } \\
(\mu \mathrm{m})\end{array}$ & $\begin{array}{c}\mathbf{P z} \\
(\mu \mathbf{m})\end{array}$ & $\begin{array}{c}\mathbf{P q} \\
(\mu \mathrm{m})\end{array}$ \\
\hline $\begin{array}{l}\text { White Fir } \\
\text { (Abies alba Mill) }\end{array}$ & 440 & G & $\begin{array}{l}\text { Mean } \\
\text { SD }\end{array}$ & $\begin{array}{l}4,68 \\
2,13\end{array}$ & $\begin{array}{l}44,96 \\
10,25\end{array}$ & $\begin{array}{l}33,50 \\
8,95\end{array}$ & $\begin{array}{l}5,85 \\
2,64\end{array}$ \\
\hline $\begin{array}{l}\text { Aleppo Pine } \\
\text { (Pinus halepensis Mill) }\end{array}$ & 550 & A & $\begin{array}{l}\text { Mean } \\
\text { SD } \\
\end{array}$ & $\begin{array}{l}5,01 \\
2,58 \\
\end{array}$ & $\begin{array}{l}52,38 \\
11,58 \\
\end{array}$ & $\begin{array}{l}36,20 \\
9,54 \\
\end{array}$ & $\begin{array}{l}6,74 \\
3,11 \\
\end{array}$ \\
\hline $\begin{array}{l}\text { Walnut } \\
\text { (Juglans regia L.) }\end{array}$ & 655 & SR & $\begin{array}{l}\text { Mean } \\
S D\end{array}$ & $\begin{array}{l}4,89 \\
2,46\end{array}$ & $\begin{array}{l}47,84 \\
10,96\end{array}$ & $\begin{array}{l}35.48 \\
9,01\end{array}$ & $\begin{array}{l}6,58 \\
2,93\end{array}$ \\
\hline $\begin{array}{l}\text { European Beech } \\
\text { (Fagus sylvatica L.) }\end{array}$ & 730 & D & $\begin{array}{l}\text { Mean } \\
\text { SD }\end{array}$ & $\begin{array}{l}4,43 \\
1,92\end{array}$ & $\begin{array}{l}42,27 \\
9,57\end{array}$ & $\begin{array}{l}31,41 \\
8,57\end{array}$ & $\begin{array}{l}5,60 \\
2,04\end{array}$ \\
\hline $\begin{array}{l}\text { White Oak } \\
\text { (Quercus petraea Liebl) }\end{array}$ & 780 & $\mathrm{R}$ & $\begin{array}{l}\text { Mean } \\
S D\end{array}$ & $\begin{array}{l}5,68 \\
3,05\end{array}$ & $\begin{array}{l}48,95 \\
10,83\end{array}$ & $\begin{array}{l}42,82 \\
9,58\end{array}$ & $\begin{array}{l}7,46 \\
2,98\end{array}$ \\
\hline
\end{tabular}

${ }^{\mathrm{a}} \mathrm{A}$ - abrupt-transition softwood; G - gradual-transition softwood; R - ring-porous hardwood; $\mathrm{D}$ - diffuse-porous hardwood; SR - semi-ring-porous hardwood

In the table 3 , the calculated average values of the surface roughness parameters and their standard deviations are given based on measurements for different wood species specimens after their processing in the sanding machine using a sandpaper of 120 grit size.

Table 3. Average values of the surface roughness parameters after processing in the sanding machine.

\begin{tabular}{|c|c|c|c|c|c|c|c|}
\hline Species & $\begin{array}{l}\text { Density } \\
\left(\mathrm{kg} / \mathrm{m}^{3}\right)\end{array}$ & $\begin{array}{c}\mathbf{E W} / \mathbf{L W} \\
\text { transition }^{\mathrm{a}}\end{array}$ & & $\begin{array}{c}\mathbf{P a} \\
(\mu \mathrm{m})\end{array}$ & $\begin{array}{c}\text { Py } \\
(\mu \mathrm{m})\end{array}$ & $\begin{array}{c}\mathbf{P z} \\
(\mu \mathrm{m})\end{array}$ & $\begin{array}{c}\mathbf{P q} \\
(\mu \mathbf{m})\end{array}$ \\
\hline $\begin{array}{l}\text { White Fir } \\
(\text { Abies alba) }\end{array}$ & 440 & $\mathrm{G}$ & \begin{tabular}{|l|} 
Mean \\
$S D$
\end{tabular} & $\begin{array}{l}3,32 \\
1,87 \\
\end{array}$ & $\begin{array}{l}33.96 \\
8,64\end{array}$ & $\begin{array}{l}29,54 \\
7,83 \\
\end{array}$ & $\begin{array}{l}4,10 \\
2,05\end{array}$ \\
\hline $\begin{array}{l}\text { Aleppo Pine } \\
(\text { Pinus halepensis })\end{array}$ & 550 & A & $\begin{array}{l}\text { Mean } \\
S D\end{array}$ & $\begin{array}{l}4,25 \\
2,21 \\
\end{array}$ & $\begin{array}{l}38,54 \\
12,24 \\
\end{array}$ & $\begin{array}{l}36,20 \\
10,57 \\
\end{array}$ & $\begin{array}{l}5,51 \\
2,76 \\
\end{array}$ \\
\hline $\begin{array}{l}\text { Walnut } \\
\text { (Juglans regia) }\end{array}$ & 655 & SR & $\begin{array}{l}\text { Mean } \\
S D\end{array}$ & $\begin{array}{l}3,97 \\
2,18\end{array}$ & $\begin{array}{l}41,51 \\
9,92\end{array}$ & $\begin{array}{l}31.39 \\
8,54\end{array}$ & $\begin{array}{l}5,38 \\
2,16\end{array}$ \\
\hline $\begin{array}{l}\text { European Beech } \\
(\text { Fagus sylvatica })\end{array}$ & 730 & D & \begin{tabular}{|l|} 
Mean \\
$S D$
\end{tabular} & $\begin{array}{l}2,89 \\
1,65 \\
\end{array}$ & $\begin{array}{l}30,07 \\
8,24\end{array}$ & $\begin{array}{l}20,55 \\
7,35\end{array}$ & $\begin{array}{l}3,88 \\
1,82 \\
\end{array}$ \\
\hline $\begin{array}{l}\text { White Oak } \\
\text { (Quercus petraea) }\end{array}$ & 780 & $\mathrm{R}$ & $\begin{array}{l}\text { Mean } \\
S D\end{array}$ & $\begin{array}{l}4,62 \\
2,04\end{array}$ & $\begin{array}{l}41,34 \\
9,14\end{array}$ & $\begin{array}{l}37,84 \\
9,16\end{array}$ & $\begin{array}{l}6,02 \\
3,07\end{array}$ \\
\hline
\end{tabular}

${ }^{\text {a A }}$ - abrupt-transition softwood; G - gradual-transition softwood; R - ring-porous hardwood; D - diffuse-porous hardwood; SR - semi-ring-porous hardwood 
In both tables 2 and 3 are given the structural characteristics of tested species. There is a difference of wood density in a growth ring between early wood (EW) and late wood (LW). The softwood tested species are classified in gradual transition (G) and abrupt transition (A), while the hardwood tested species are classified according wood porosity: diffuse porous (D), semi-ring porous (SR), and ring porous (R).

From the results given on the tables $2 \& 3$ we can conclude that the measured values or the surface roughness parameters $\mathrm{Pa}, \mathrm{Py}, \mathrm{Pz}$, and $\mathrm{Pq}$ are similar to the values given in the field literature. Some deviations of the measured value from the expected ones both in the case of measurements at different points or between parameters measured at the same point can be explained by the anisotropic nature of the wood.

It results that the average values of surface roughness parameters for broadleaved species such as European beech and oak are different. Beech has a smoother surface roughness than oak. The same can be said for the white fir, which has a smoother surface roughness than the Aleppo pine.

A one-way ANOVA analysis showed ( Table 4 ) that there is a significant effect of species in the average values of the surface roughness parameters, $\mathrm{F}(3,16)=264,05, \mathrm{p}<0,05$.

Table 4. Main ANOVA summary table.

\begin{tabular}{lrcrccc}
\hline Source of Variation & \multicolumn{1}{c}{ SS } & $d f$ & \multicolumn{1}{c}{$M S$} & $F$ & $P$-value & $F$ crit \\
\hline Between Groups & 6770,572775 & 3 & 2256,858 & $\mathbf{2 6 4 , 0 5}$ & $7,81 \mathrm{E}-14$ & $\mathbf{3 , 2 4}$ \\
Within Groups & 136,75248 & 16 & 8,54703 & & & \\
Total & 6907,325255 & 19 & & & & \\
\hline
\end{tabular}

The differences between roughness parameters mentioned above can be explained by the influence on the roughness of the wood surface of the wood texture and the texture uniformity. Species with a finer texture (smooth and glassy) such as beech or white fir has a smoother surface roughness compared to species with a coarse texture (soft and rough) such as oak and Aleppo pine. Also the uniformity of the texture or the size and distribution of the pores (particularly within the early wood zone), can give a very uneven wood texture. Normally diffuse porous woods with small pores tend to be the most evenly textured compared to the wood species such as oak, which has very large and open pores.

The influence of the cutting regime parameters such as rotation speed, feed speed and chip thickness on the parameters of the surface roughness was tested without yielding significant differences of roughness parameters.

It was found, as expected, a proportional relationship between the mean roughness depth $(\mathrm{Pz})$ and chip thickness. It showed that a higher level of chip thickness caused a lower quality of wood surface. In the figure 2 the relationship between the mean roughness depth $(\mathrm{Pz})$ and the chip thickness is shown, for beech tested specimens, processed in a planning machine with a rotation speed of $5600 \mathrm{rpm}$. 


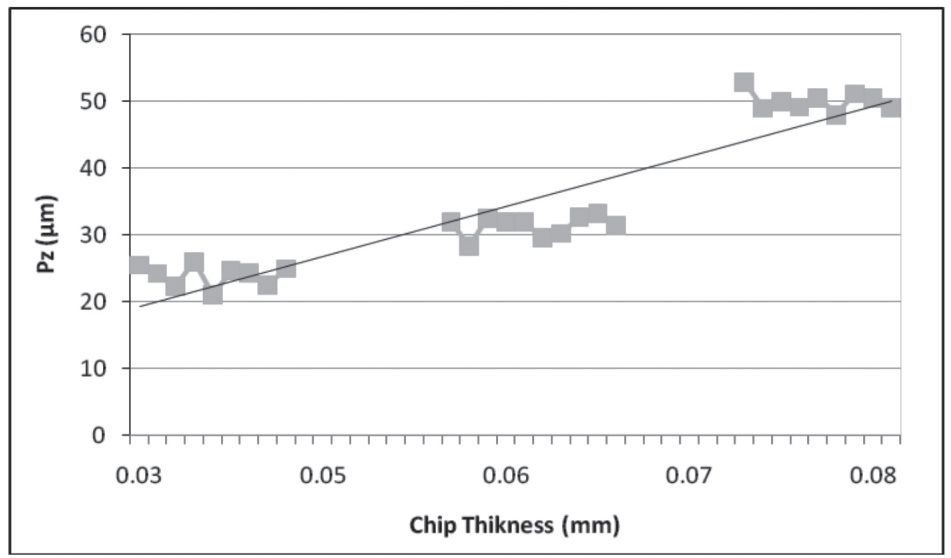

Figure 2. Relationship between surface roughness $\mathrm{Pz}(\mu \mathrm{m})$ and chip thickness (mm) for European beech (Fagus sylvatica)

\section{CONCLUSIONS}

The study involved five species with different wood density namely white fir (Abies alba), Aleppo pine (Pinus halepensis), European beech (Fagus sylvatica), walnut (Juglans regia) and white oak (Quercus petraea), with the purpose of studying the impacts of species characteristics mainly density on the surface roughness.

Specimens from the five wood species were tested for the parameters of wood surface roughness and the measurements results showed similar average values of roughness parameters as in the field literature. Some deviations of the measured value from the expected ones both in case of measurements at different points or between parameters measured in the same point could be explained by the anisotropic nature of the wood.

The differences of the parameters of surface roughness for different species could also be explained by the influence of the wood texture and wood texture uniformity. Beech and white fir with a finer wood texture had a smother surface roughness than oak and Aleppo pine. Also the uniformity of the texture or the size and distribution of the pores can give wood a very uneven texture explaining the differences between measurements at different points of the same species specimen.

The change of the cutting regime parameters as rotation speed, feed speed and chip thickness on the parameters of the surface roughness did not significantly influence the surface roughness parameters. 


\section{REFERENCES}

Aguilera, A.; Muñoz, H. 2011. Rugosidad superficial y potencia de corte en el cepillado de Acacia melanoxylon y Sequoia sempervirens. Maderas. Cienc Tecnol 13(1): 19-28.

Aguilera, A.; Zamora, R. 2009. Surface roughness in sapwood and heartwood of Blackwood (Acacia melanoxylon R. Br.) machined in 90-0 direction. European Journal of Wood Products 67: 297-301.

Deutsches Institut Für Normung. DIN. 1990. Determination of Surface Roughness Values of The Parameters By Means of Electrical Contact (stylus) Instruments; Terminology, Measuring Conditions. DIN $4768(1990-05)$

Fujiwara, Y.; Fujii, Y.; Okumura, SH. 2005. Relationship between roughness parameters based on material ratio curve and tactile roughness for sanded surfaces of two hardwoods. Journal of Wood Science 51:274-277.

Funck, J.W.; Forrer, J.B.; Butler, D.A.; Brunner, C.C.; Maristany, A.G. 1992. Measuring surface roughness on wood: a comparison of laser scatter and stylus tracing approaches. SPIE 1821:173-184.

Goli, G. 2003. Superficie del legno ottenuta mediante fresatura: studio delle meccaniche di formazione e dei relativi difetti. Surfaces de bois obtenues par de' foncage: e' tude de la me' canique de formation et des de' fauts induits. Ph.D. Thesis. Universita' degli studi di Firenze. Ecole nationale superieur d'arts et metier - Cluny.

Goli, G.; Fioravanti, M.; Sodini, N.; Uzielli, L.; Taglia, A.D. 2005. Wood processing: a contribution to the interpretation of surface origin according to grain orientation. Paper presented in COST E35 Roesenheim Workshop. Eds. Stanzl-Tschegg, S.E., Sinn, G. BOKU - University of Natural Resources and Applied Life Sciences, Vienna.

Goli, G.; Marchal, R.; Uzielli, L. 2004. Classification of wood surface defects according to their mechanical formation during machining. Paper presented in the $2^{\text {nd }}$ International Symposium on Wood Machining. Eds. Stanzl-Tschegg, S.E., Gindl, M., Sinn, G. BOKU - University of Natural Resources and Applied Life Sciences, Vienna pp. 315-324.

Goli, G.; Marchal, R.; Uzielli, L. 2004. Classificazione qualitativa dei difetti con metodo visuale. Xylon 2:44-48.

Hecker, M.; Becker, G. 1995. Surface roughness of Douglas fir veneer as a result of silviculture management. Paper presented in the IUFRO XX World Congress. Tampere, Finland. August 6-12, p 352.

International Organization For Standardization 1996. ISO 3274: Geometrical Product Specifications (GPS), Surface Texture, Profile Method, Nominal characteristics of contact (stylus) instruments. ISO, Geneva, Switzerland.

International Organization For Standardization 1998. ISO 4287: Geometrical Product Specifications (GPS), Surface Texture, Profile Method, Terms, Definitions and Surface Texture Parameters. ISO, Geneva, Switzerland.

Krisch, J.; Csiha, C. 1999. Analyzing wood surface roughness using an S3P perthometer and computer based data processing. Paper presented in the XIII Sesja Naukowa "Badania dla Meblarstwa" Poland. 
Lavery, D.J.; Mclarnontul, D.; Taylor, J.M.; Moloney, S.; Atanackovic, A. 1995. Parameters affecting the surface finish of planed sitka spruce. Forest Products Journal 45:45-50.

Lemaster, R.; Dornfeld, D. 1982. Measurement of surface quality of sawn and planed surfaces with a laser. Paper presented in the Seventh Wood Machining Seminar. October 18-20, University of California, Forest Products Laboratory, Richmond, CA, pp 54-61.

Mitchell, P.; Lemaster, R. 2002. Investigation of machining parameters on the surface quality in routing soft maple. Forest Products Journal 52(6):85-90.

Sinn, G.; Sandak, J.; Ramananantoandro, T. 2009. Properties of wood surfaces - Characterization and measurement. A review COST Action E35 2004-2008: Wood machining - micromechanics and fracture. Holzforschung 63(2):196-203.

Tanaka, C. 1991. Relationship between surface finish quality and acoustic emission count rate in circular sawing. Paper presented in the Tenth International Wood Machining Seminar. October 21-23, University of California, Forest Products Laboratory, Richmond, CA, pp 308-316.

The American Society of Mechanical Engineers. ASME. 2009. Surface texture. Surface roughness, waviness and lay. ASME. B46.1: 2009 